\title{
Design a Fuzzy Expert System for Pediatrics Diseases Diagnosis
}

\author{
Nada N. Saleem \\ Adepa Ismaeel \\ Nada_N_S@uomosul.edu.iq \\ College of Computer Sciences and Mathematics $\backslash$ University of Mosul
}

Received on: 25/9/2007

Accepted on: 20/4/2008

\begin{abstract}
Fuzzy logic is a branch of artificial intelligence techniques, it deals with uncertainty in knowledge that simulates human reasoning in incomplete or fuzzy data. Fuzzy relational inference that was applied in medical diagnosis was used within the medical knowledge base system to deal with diagnostic activity, treatment recommendation and patient's administration.

In this research, a medical fuzzy expert system named (PedFES) has been developed for diagnosis and decision making of general pediatrics diseases.

The (PedFES) is a rule based fuzzy expert system, the results of laboratory analysis are inserted into the system. This system can define the probable diagnosis depending on these data, and later on it can pick out the most probable one for disease.

Keyword: fuzzy logic, fuzzy expert system, Pediatrics diseases.

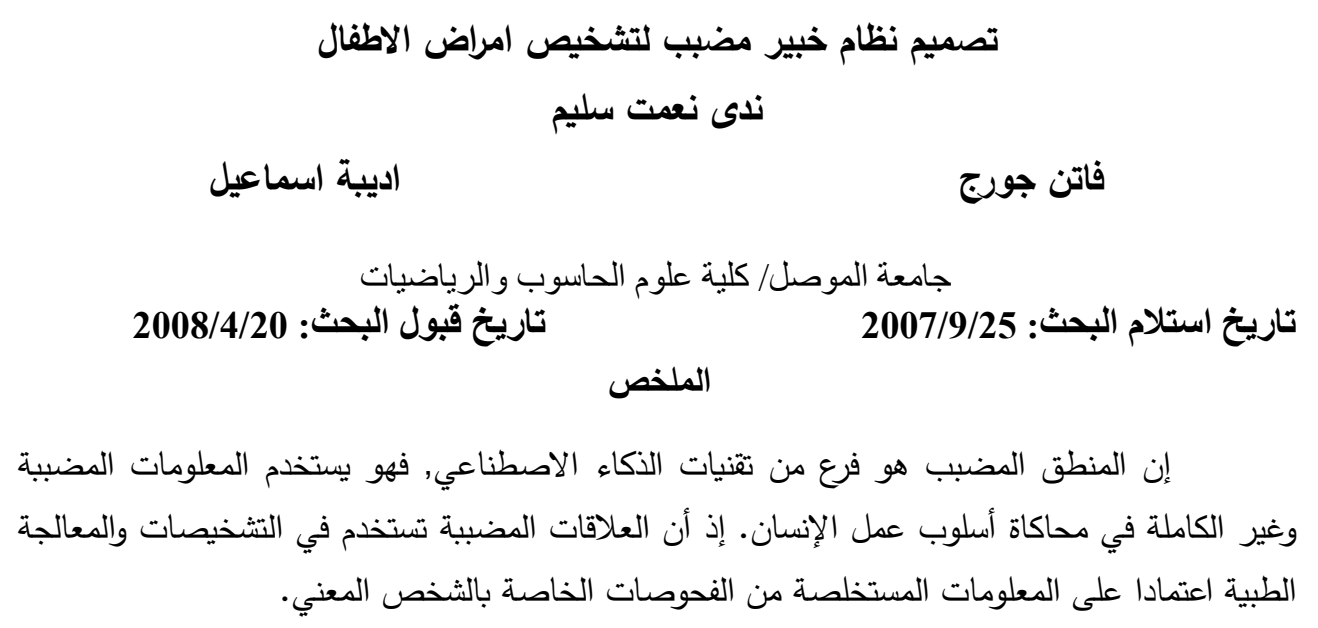




$$
\begin{aligned}
& \text { تم في هذا البحث تصميم نظام مضبب خبير يدخل في متتاول المجال الطبي ويساعد في اتخاذ } \\
& \text { القرار فيما يتعلق بتشخيص أمراض الأطفال. } \\
& \text { يعتمد تثخيص النظام المضبب الخبير لتحديد نوعية المرض المصنياب به به على نتائج التحاليل } \\
& \text { المختبرية, ويستخدم النظام في اتخاذ القرار وتثخيص الأمراض الثائعة الخاصة بالأطفال. } \\
& \text { الكلمات المفتاحية: المنطق المضبب, النظام الخبير المضبب, امراض الاطفال }
\end{aligned}
$$

\section{Introduction}

In recent years, computational intelligence has been used to solve many complex problems by developing intelligent systems, and fuzzy logic has proved to be a powerful tool for decision making systems, such as expert systems and pattern classification systems. Fuzzy set theory has already been used in some medical expert systems [1].

One challenge in medical expert systems is the problem of imprecision and uncertainty in both data and knowledge [2]. In practice, it is important to develop techniques for handling such imprecision and uncertainty to enhance the robustness and performance of medical expert systems. Fuzzy logic and fuzzy set theory [3] provide a good framework for managing uncertainty and imprecision in medicine [4], [5], [6] and have been applied to a number of area [7], [5], [8].

The successful development of a fuzzy model for a particular application domain is a complex multi-step process, in which the designer is faced with a large number of alternative implementation strategies. The principle alternatives are in the selection of:

- Inference methodology

- Linguistic variables and fuzzy terms

- Rule set

- Fuzzy operators

- Membership functions

The effect of a fuzzy system is defined by the set of vectors comprising the fuzzy output variables that are obtained from a set vectors representing input variables. Even the simplest modification to the fuzzy system, may alter the input-output mapping of the fuzzy model. Thus the behavior of a fuzzy system is governed by a combination of all these design choices. In a given application there is the additional process of defuzzification to map the output fuzzy sets to the real world. 


\section{Artificial Intelligence in Medicine}

Artificial Intelligence (AI) is a study to emulate human intelligence into computer technology. The potential of AI in medicine has been expressed by a number of researchers. [9] summarized the potential of AI techniques in medicine as follows:

- Provide a laboratory for the examination, organization, representation and cataloging of medical knowledge.

- Produces new tools to support medical decision-making, training and research.

- Integrates activities in medical, computer cognitive and other sciences.

- Offers a content-rich discipline for future scientific medical specialty.

\section{Fuzzy Control in Medicine}

Fuzzy control techniques have recently been applied in various medical processes. Fuzzy control compared to classical control theory, which is a fuzzy logic approach to control, offers the following advantages [10], [11]:

- It can be used in systems, which cannot be easily modeled mathematically. In particular systems with non-linear responses that are difficult to analyze may respond to a fuzzy control approach.

- As rule-based approach to control, fuzzy control can be used to efficiently represent an expert's knowledge about a problem.

- Continuous variables may be represented by linguistic constructs that are easier to understand, making the controller easier to implement and modify.

- Fuzzy controllers may be less susceptible to system noise and parameter changes, in other words, they will be more robust.

- Complex process can be controlled by relatively few logical rules permitting an easily comprehensible controller design and faster computation.

In other words, fuzzy control can be best applied to production tasks, that heavily rely on human experience and intuition, and which therefore rule out the application conventional control methods. 


\section{Medical Knowledge as a Fuzzy Relation}

The relationship between symptoms and diagnosis by the concept of medical knowledge was introduced. "In a given pathology, we denote by $\mathrm{S}$ a set of symptoms, D a set of diagnoses and $\mathrm{P}$ a set of patients. What we call medical knowledge is a fuzzy relation, generally denoted by $R$, from $S$ to $D$ expressing of diagnoses". Zadeh's max-min compositional rule is adopted as an inference mechanism. It accepts fuzzy descriptions of the patient's symptoms and infers fuzzy descriptions of the patient's diseases by means of the fuzzy relationships. If a patient's symptom is $S_{i}$ then the patient's state in terms of diagnoses in a fuzzy set $D_{j}$ with the following membership function [12], [13]:

$$
\mu_{D_{j}}(d)=\max _{s \in S} \min \left\{\mu_{S_{i}}(s) ; \mu_{R}(s, d)\right\}, s \in S, d \in D
$$

$\mu_{\mathrm{R}}(\mathrm{s}, \mathrm{d})$ is the membership function of the fuzzy relation "medical knowledge".

With $\mathrm{P}$, a set of patients, and a fuzzy relation $\mathrm{Q}$ from $\mathrm{P}$ to $\mathrm{S}$, and by "max-min" composition" we get the fuzzy relation $\mathrm{T}=\mathrm{Q} \times \mathrm{R}$ with the membership function [14].

$$
\mu_{T}(p, d)=\max _{s \in S} \min \left\{\mu_{Q}(p, s) ; \mu_{R}(s, d)\right\}, p \in P, s \in S, d \in D
$$

\section{The Developed Pediatrics Fuzzy Expert System (PedFES)}

The design structure, application and working principles of a Pediatrics Fuzzy Expert system (PedFES) has been described for diagnosis of general pediatrics diseases.

The (PedFES) is a parallel rule-firing system, in which all fireable rules are fired effectively at one time.

During the process with the medical expert system (PedFES), laboratory test results are converted into fuzzy compatibility values reaching from zero to unity by consideration of the linguistic medical concepts. These fuzzified data are used to infer diagnosis with knowledge contained in a knowledgebase. Fuzzy relations were calculated for all linguistic medical concepts between test results and diagnosis by using the obtained fuzzy sets with the given set of patient data. 


\subsection{Medical Knowledgebase}

The examination and laboratory data of the system assigned for the pediatrics patients were collected from Al-Kansaa Teaching Hospital. The data then are inserted into the system (PedFES), for the design process, the Fasting Blood Sugar (FBS), Cholesterol and PH examinations are used for Diabetes Mellitus diagnosis (MELT).

The Urine Culture (UC), Serum Creatiniue (S.creatinine) and General Urine Examination (GUE) are used for Urinary Tract Infection disease (UTI) diagnosis. Total Serum Bilirubin (T.S.B_direct), (T.S.B_in_direct) and Hemoglobin (Hb) examination are used for diagnosis of Jaundice disease (JD).

The units of the used factors are: FBS $(\mathrm{mg} / 100 \mathrm{ml})$, Cholesterol $(\mathrm{mg} / 100 \mathrm{ml})$, S.creatinine $(\mathrm{mg} / 100 \mathrm{ml})$, T.S.B_direct and T.S.B_in_direct $(\mathrm{mg} / 100 \mathrm{ml}), \mathrm{Hb}(\mathrm{gm} / 100 \mathrm{l})$.

\subsection{Inference Methodology}

The fuzzy control application structure as shown in figure (1) has nine crisp input variables, these input parameters represent the patients data. The mamdani model of inference was used. All (PedFES) fuzzy rules were of the form "If $\mathrm{x}_{1}$ is $\mathrm{A}_{1}$ and $\mathrm{y}_{1}$ is $\mathrm{B}_{1}$ then $\mathrm{z}_{1}$ is $\mathrm{C}_{1}$ ", where $\mathrm{A}_{1}, \mathrm{~B}_{1}$ and $\mathrm{C}_{1}$ are fuzzy sets. The max-min operators were used for implication throughout for implementing a (PedFES). It was necessary to obtain crisp output for the purposes of evaluation of the fuzzy model, center-of-gravity (centroid) defuzzification was used to produce crisp values on an arbitrary scale of the fuzzy output variable Pediatrics Patients Disease (PPD).

\subsection{Linguistic Variables and Fuzzy Terms}

Each of the nine input parameters was assigned a linguistic variable and examination of the data and rules showed that each could naturally be divided into two or three fuzzy terms corresponding to meanings of Low $(\mathrm{L})$, Normal $(\mathrm{N})$ and High $(\mathrm{H})$ for the types of laboratory examinations.

One output fuzzy variable was used, from the rules it was determined that the output fuzzy variable PPD had eight linguistic terms in it's term_set, these terms represent the pediatric diseases. 


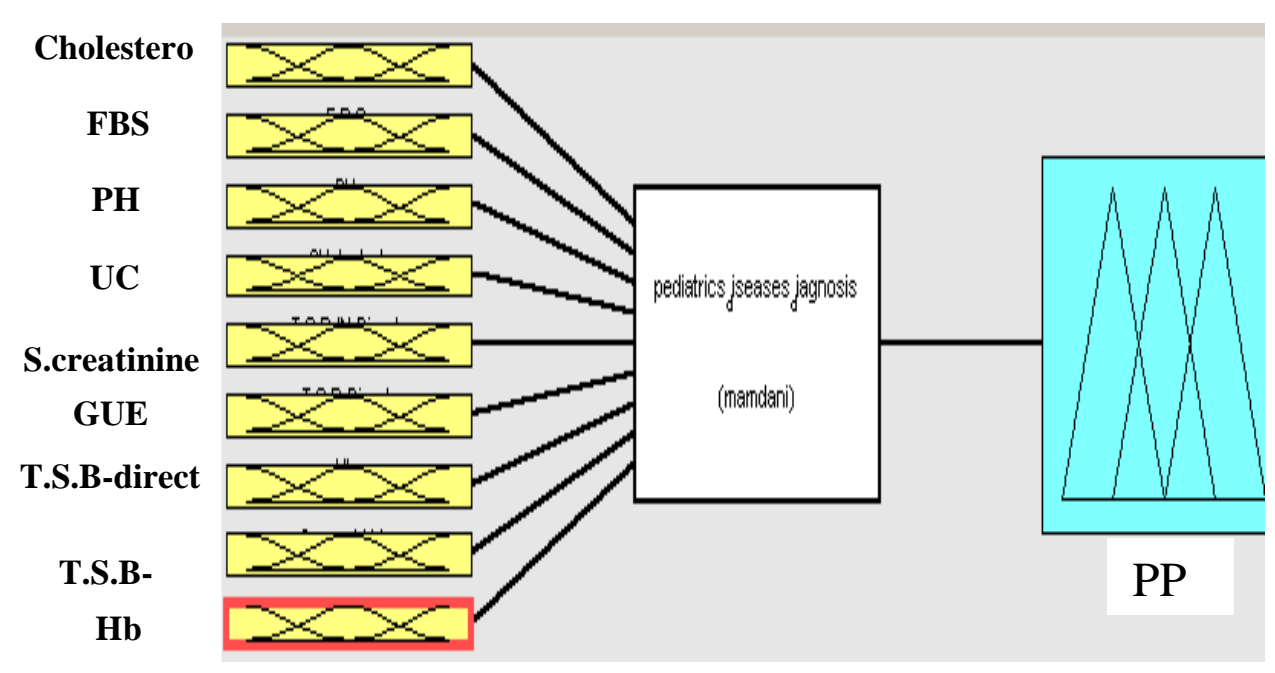

Figure(1): The structure of the pediatrics fuzzy expert system

\subsection{Rule Set}

PedFES must contain a set of rules that can deal with fuzzy tags, fuzzy sets and relations and must provide an appropriate output which corresponds to a particular input.

The rules for the fuzzy expert system were obtained by means of knowledge expert-doctor, and had been carefully refined to form a complete and consistent set of classifiers. Part of the developed (PedFES) fuzzy knowledge base rules are shown in the table (1), total of 84 rules are formed as shown in the appendix. 
Table (1): (PedFES) fuzzy rules

\begin{tabular}{|c|c|c|c|c|c|c|c|c|c|c|}
\hline $\begin{array}{l}\text { Rule } \\
\text { No. }\end{array}$ & FBS & PH & Cholestrol & GUE & $\mathbf{U C}$ & S.creatin & $\begin{array}{l}\text { TSB_ } \\
\text { Direct }\end{array}$ & \begin{tabular}{|c|} 
TSB \\
in_direct
\end{tabular} & HB & PPD \\
\hline & & & $\ldots$ & 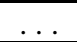 & 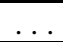 & $\ldots$ & $\ldots$ & $\ldots$ & $\ldots$ & . \\
\hline Rule 2 & $\mathrm{~N}$ & $\overline{\mathrm{N}}$ & $\overline{\mathrm{N}}$ & $\mathrm{N}$ & $\mathrm{N}$ & $\overline{\bar{N}}$ & $\overline{\mathrm{H}}$ & $\mathrm{N}$ & $\bar{L}$ & $\begin{array}{l}\mathrm{JD} \\
\end{array}$ \\
\hline \begin{tabular}{|l|l|l} 
Rule 3 \\
\end{tabular} & $\bar{N}$ & $\bar{N}$ & $\overline{\mathrm{N}}$ & $\overline{\mathrm{H}}$ & PH & $\overline{\mathrm{H}}$ & $\overline{\mathrm{N}}$ & $\overline{\mathrm{N}}$ & $\bar{N}$ & 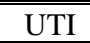 \\
\hline & 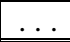 & $\ldots$ & $\ldots$ & $\ldots$ & $\ldots$ & $\ldots$ & $\ldots$ & $\ldots$ & $\ldots$ & $\ldots$ \\
\hline \begin{tabular}{|l} 
Rule 5 \\
\end{tabular} & $\mathrm{~N}$ & $\mathrm{~N}$ & $\overline{N \mathrm{~N}}$ & $\overline{\mathrm{H}}$ & $\mathrm{H}$ & $\overline{\mathrm{N}}$ & $\mathrm{N}$ & $\mathrm{N}$ & $\mathrm{N}$ & $\begin{array}{l}\text { UTI } \\
\end{array}$ \\
\hline . & $\ldots$ & $\ldots$ & $\ldots$ & $\ldots$ & $\ldots$ & $\ldots$ & $\ldots$ & $\ldots$ & $\ldots$ & $\ldots$ \\
\hline$\ldots$ & $\ldots$ & $\ldots$ & $\ldots$ & $\ldots$ & $\ldots$ & $\ldots$ & $\ldots$ & $\ldots$ & $\ldots$ & $\ldots$ \\
\hline$\ldots$ & $\ldots$ & $\ldots$ & $\ldots$ & $\ldots$ & $\ldots$ & $\ldots$ & $\ldots$ & $\ldots$ & $\ldots$ & $\ldots$ \\
\hline Rule 25 & $\mathrm{H}$ & $\mathrm{L}$ & $\mathrm{H}$ & $\mathrm{N}$ & $\mathrm{N}$ & $\mathrm{N}$ & $\mathrm{H}$ & $\mathrm{N}$ & $\mathrm{L}$ & $\begin{array}{l}\text { MELT } \\
\text { \& JD }\end{array}$ \\
\hline$\cdots$ & $\ldots$ & $\ldots$ & $\ldots$ & $\ldots$ & $\ldots$ & $\ldots$ & $\ldots$ & $\ldots$ & $\ldots$ & $\ldots$ \\
\hline Rule 40 & $\mathrm{H}$ & $\mathrm{L}$ & $\mathrm{H}$ & $\mathrm{N}$ & $\mathrm{H}$ & $\mathrm{H}$ & $\mathrm{N}$ & $\mathrm{N}$ & $\mathrm{N}$ & $\begin{array}{l}\text { UTI\& } \\
\text { MELT }\end{array}$ \\
\hline & & & $\because$ & & & & & & & \\
\hline
\end{tabular}

For example Rule 25 can be interpreted as follows:

Rule 25: if patient's FBS is High, patient's PH is Low, patient's Cholestrol is High and patient's GUE is Normal, patient's UC is Normal, patient's S.crartin is Normal and patient's TSB_Direct is High, patient's TSB_indirect is Normal and patient's HB is Low, then patient has Diabetes Mellitus and Jaundice diseases.

\subsection{Fuzzy Operations}

The probabilistic family of operators was chosen for the reason that all the rules features conjunction of the input linguistic variables use the fuzzy conjunction operators.

The min operator is used for conjunction, the overall truth value of such a rule will obviously be determined solely by the reasoning of the clinician in considering all the parameters.

After the truth degree of each rule is determined, we calculate the truth degree of all rules by taking max between working rules.

\subsection{Membership functions}

Fuzzy membership functions for the medical factors for the mentioned laboratory parameters are calculated by the following functions as shown in the figure (2). 

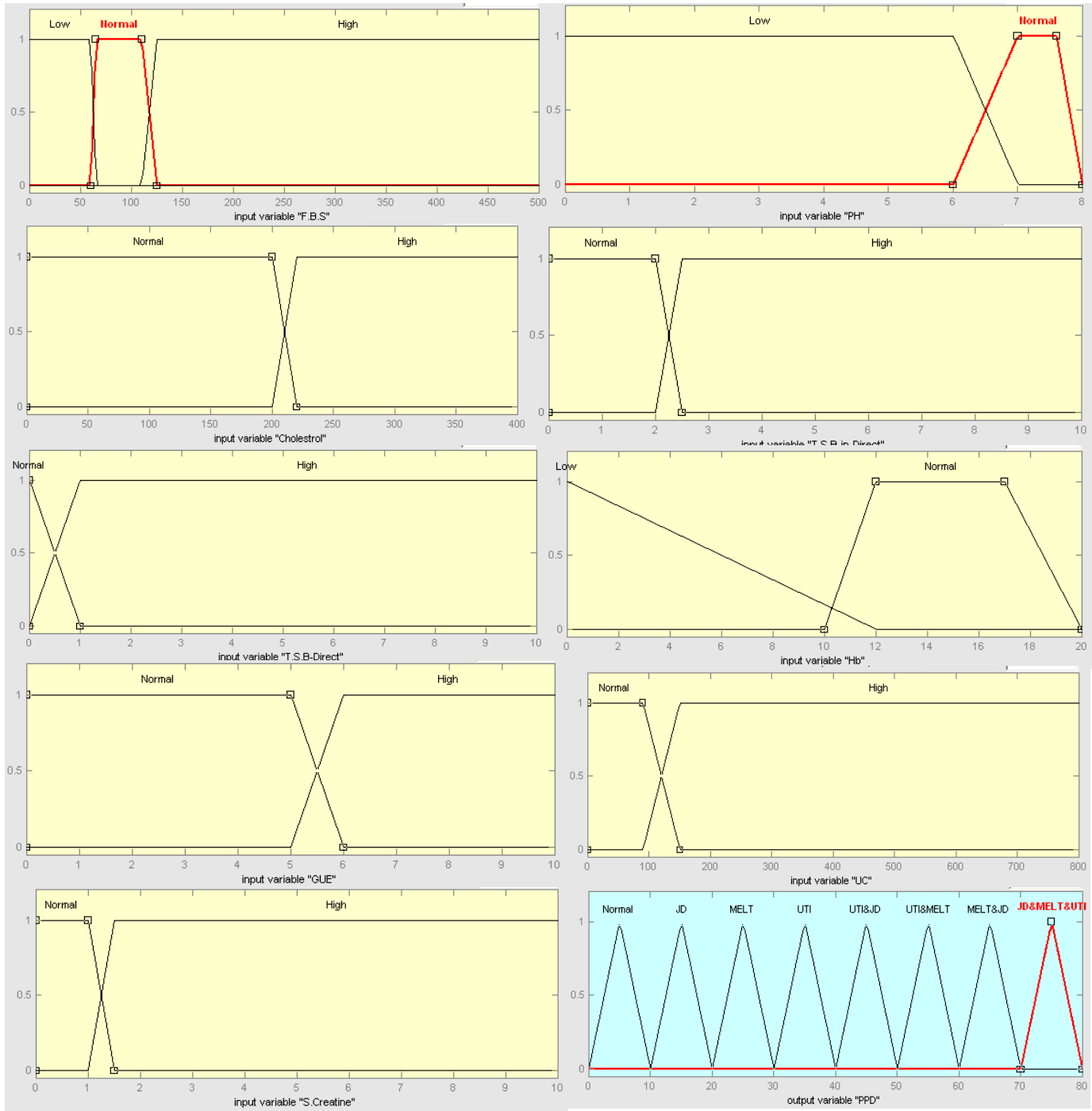

Figure(2): The membership functions of input-output terms

\section{Experimental Results}

For the output factor PPD, the linguistic expressions represent the patients disease.

The truth degree of the rules are determined for each rule by aid of the min and then by taking max between working rules. For example, for the input patient laboratory tests values $\mathrm{FBS}=80, \mathrm{PH}=7.5$, Cholestrol=100, 
T.S.B_indirect $=0, \quad$ T.S.B_Direct $=0, \quad \mathrm{Hb}=15, \quad \mathrm{GUE}=8, \quad \mathrm{UC}=200 \quad$ and S.Crartin=1.2. the rules (3) and (5) will be fired as shown in figure (3).

From Mamdani max-min inference we will obtain the membership function of our system, max (rule 3, rule 5)=rule 5, then we calculate the crisp output. The crisp value of the PPD is calculated by the method of center of gravity defuzzifier. As you see from figure (3), the value of $\mathrm{PPD}=35$, this means that the patient has the Urinary Tract Infection (UTI) disease (see figure 2).

Another example for implementation of the (PedFES) system for patients disease diagnosis shown at figures (4 and 5) with patients laboratory tests values, fired rules (12) and (13) and values of output term PPD that refer to the diagnosis of the patient complaint.

\section{PedFES Performance Measurement}

The (PedFES) system performance can be evaluated by the equation:

$$
\text { performance }=\frac{\text { total correct number of diagnosis }}{\text { total number of sample }} \times 100
$$

The performance of the model is tested for 60 patients, the results show that the correct diagnosis using (PedFES) system is 50 and this achieves performance of $(83.3 \%)$. 


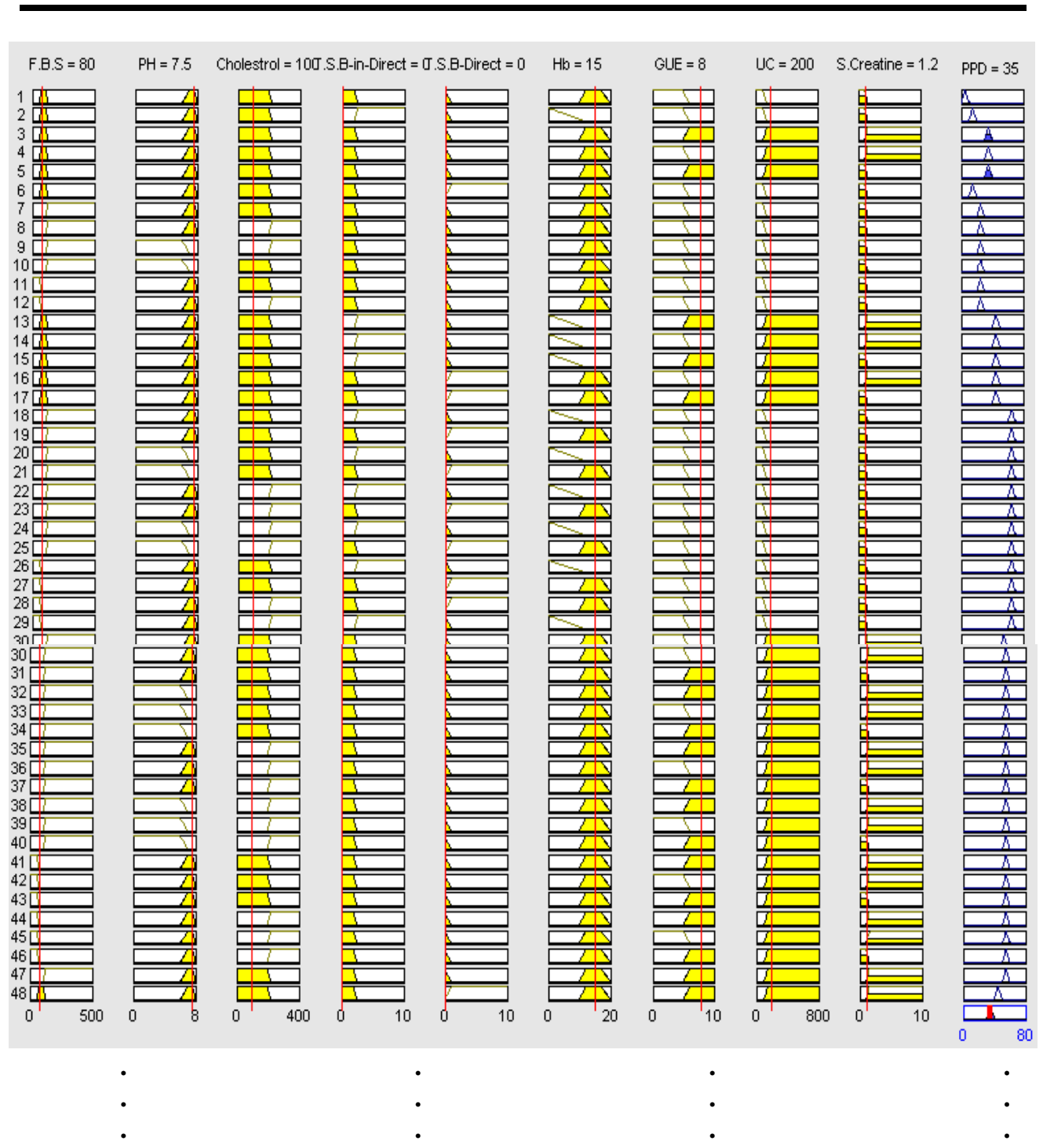

Figure(3): Calculation of the value PPD represents the diagnosis of a patient affected by Urinary Tract Infection depending on the following laboratory test values $(\mathbf{F B S}=\mathbf{8 0}, \quad \mathbf{P H}=\mathbf{7 . 5}, \quad$ Cholestrol=100, T.S.B.in.Direct=0, T.S.B.Direct $=0, \quad \mathrm{Hb}=15, \quad \mathrm{GUE}=8, \quad \mathrm{UC}=200$, S.Crartin=1.2). 


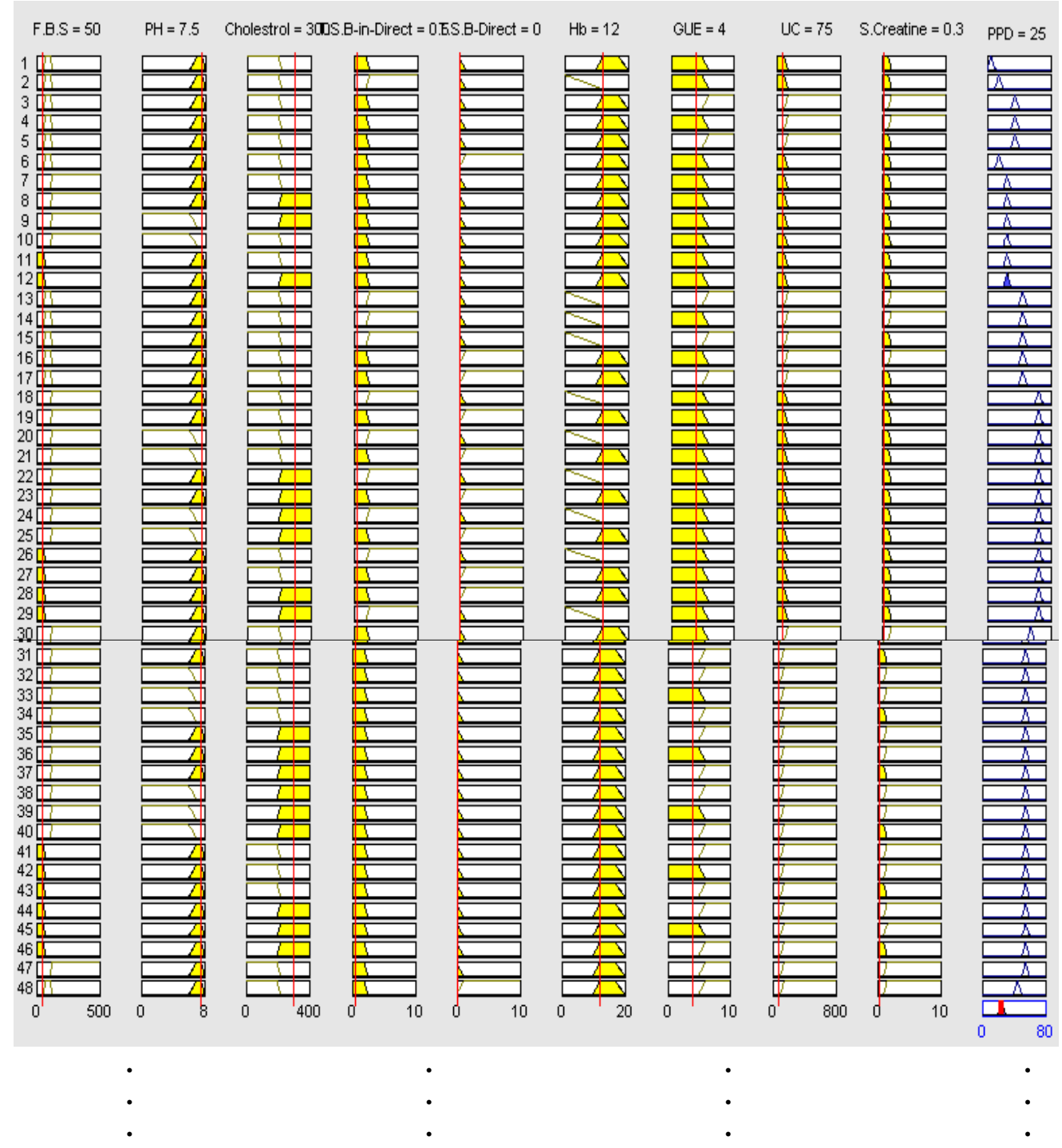

Figure(4): Calculation of the value PPD represents the diagnosis of a patient affected by Diabetes Mellitus depending on the following laboratory test values $(\mathbf{F B S}=\mathbf{5 0}, \mathbf{P H}=\mathbf{7 . 5}$, Cholestrol=300, T.S.B.in.Direct=0.5, T.S.B.Direct=0, $\mathrm{Hb}=12, \mathrm{GUE}=4, \mathrm{UC}=75, \mathrm{~S} . \mathrm{Crartin}=0.3$ ). 


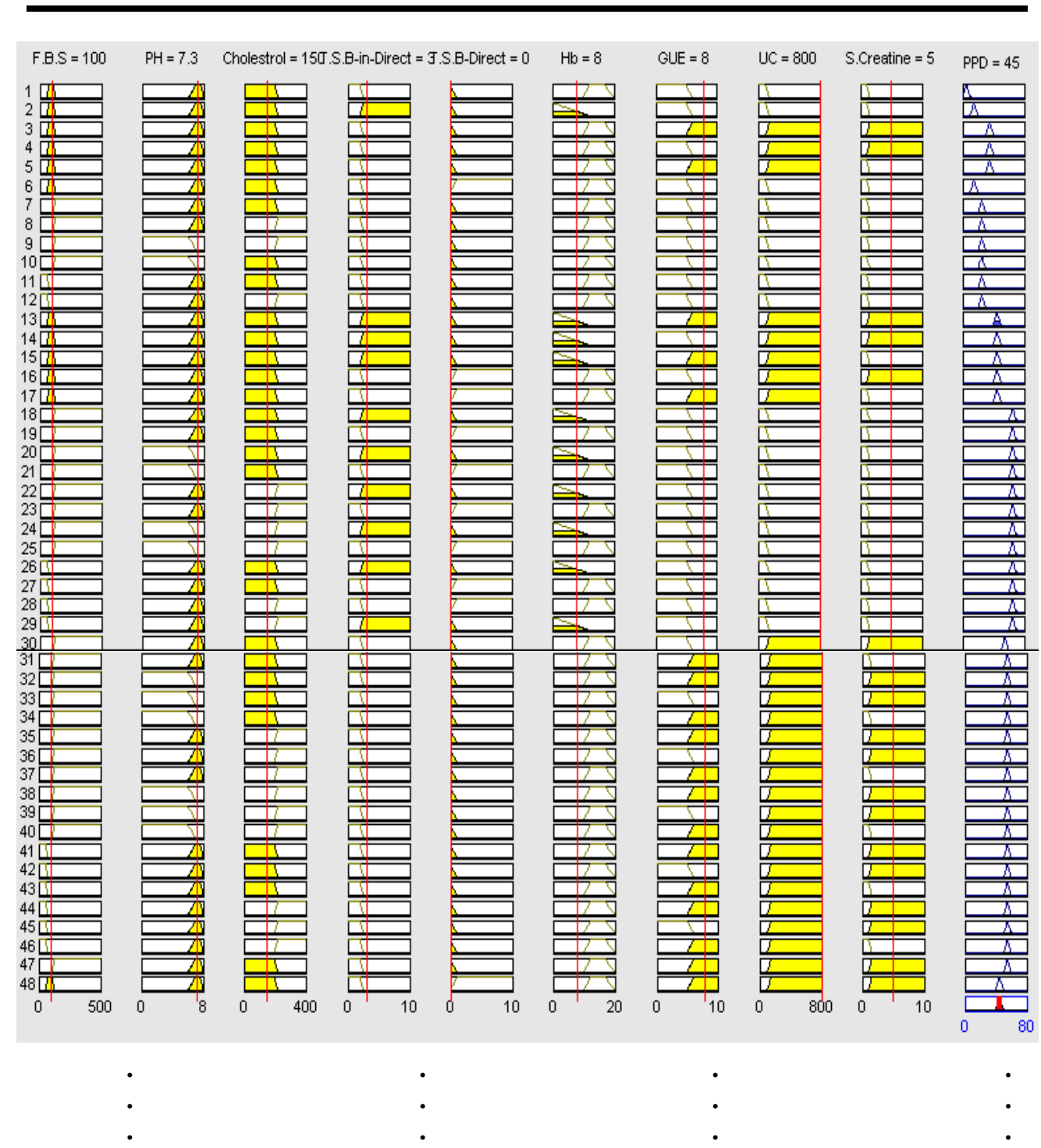

Figure(5): Calculation of the value PPD represents the diagnosis of a patient affected by Urinary Tract Infection with Jaundice depending on the following laboratory test values $(\mathbf{F B S}=100, \mathbf{P H}=7.3$, Cholestrol=150, T.S.B.in.Direct $=3, \quad$ T.S.B.Direct $=0, \quad \mathrm{Hb}=8, \quad \mathrm{GUE}=8, \quad \mathrm{UC}=800$, S.Crartin=5). 


\section{Conclusions}

The developed diagnosis module (PedFES) consists of expert system and fuzzy logic techniques to perform diagnostic tasks. A set of rules will be defined using the patients disease database as well as the expert knowledge on the disease domain (from doctors). The designed expert system uses the rules to diagnose patient's illness base on their laboratory tests. In addition, fuzzy logic is integrated to enhance the reasoning when dealing with fuzzy data. The combination of expert system and fuzzy logic that forms a hybrid (expert-fuzzy) system could increase the system performance and has been implemented successfully. 


\section{REFERENCES}

[1] Nguyen Hoang Phuong and Vladik Kreinovich, 2000, "Fuzzy logic and it's applications in medicine", Institute of Information Technology, National Center for Natural Science and Technology of Vietnam.

[2] Hughes, C. "The representation of uncertainty in medical expert systems", Medical Informatics, vol. 14, pp. 269-279, 1989.

[3] Zadeh,L.A. "The role of fuzzy logic in the management of uncertainty in expert systems", Fuzzy Set Systems, vol. 11, pp. 199227,1983 .

[4] Adlassnig, K.P. "Fuzzy set theory in medical diagnosis", IEEE Transactions Systems Man Cybernetics, vol. 16, no. 2, pp. 260-265, 1986.

[5] Cohen M.E. and D.L.Hudson. "The use of fuzzy variables in medical decision making", in Fuzzy Computing, M.M.Gupta and T.Yamakawa, Eds., pp. 263-271. Elsevier Science, North Holland, 1988.

[6] Halim, M. K.M.Ho, and A.Liu, "Fuzzy logic for medical expert systems", Annals Academy Medicine, vol. 19, no. 5, pp. 672-683, 1990.

[7] Adlassing, K.P. and G.Kolarz, "CADIAC-2: Computer-assisted medical diagnosis using fuzzy subsets", in Approximate Reasoning in Decision Analysis, MM Gupta and E Sanchez, Eds., pp. 219-247, North-Holland, New York, 1982.

[8] Watanabe, H. W.J.Yakowenko, Y.M.Kim, J.Anbe, and T.Tobi, "Application of a fuzzy discrimination analysis for diagnosis of valvular heart disease", IEEE Transactions Fuzzy Systems, vol. 2, no. 4, pp. 267-276, 1994.

[9] Hoong N.K., "Medical Information Science-Framework and Potential", International Seminar and Exhibition Computerization for Development- the Research Challenge, Universiti Pertanian Malaysia: Kuala Lumpur, pp. 191-198, 1998. 
[10] Mamdani, E. H., Qstergaard J.J., Lembessis E., "Use of Fuzzy Logic for Implementing Rule-Based Control of Industrial Processes", In: P.P.Wang, Advances in Fuzzy Sets, Possibility Theory, and Applications, New York: Plenum Press, 1989, pp. 307-323.

[11] Klement, E.P., Slany W., "Fuzzy Logic in Artificial Intelligence", Proceedings of the $8^{\text {th }}$ Austrian Artificial Intelligence Conference FLAI '93, Berlin 1995.

[12] Sanchez, E., "Medical Diagnosis and Composite Fuzzy Relations", Advances in Fuzzy Set Theory and Applications, Amsterdam: North-Holland 1979, pp. 437-444.

[13] Sanchez, E, "Resolution of Composite Fuzzy Relation Equations", Information and Control, 30, 1976, pp. 38-48.

[14] William Siler and James J. Buckley, "Fuzzy Expert Systems and Fuzzy Reasoning", Wiley Interscience, 2005. 
Appendix: Rule_base Knowledge for (PedFES) System

\begin{tabular}{|c|c|c|c|c|c|c|c|c|c|c|}
\hline $\begin{array}{c}\text { Rule } \\
\text { No. } \\
\end{array}$ & FBS & PH & Cholestrol & GUE & UC & S.creatin & \begin{tabular}{|l|} 
TSB \\
Direct
\end{tabular} & \begin{tabular}{|c|} 
TSB \\
in_direct
\end{tabular} & HB & PPD \\
\hline 1 & $\mathrm{~N}$ & $\mathrm{~N}$ & $\mathrm{~N}$ & $\mathrm{~N}$ & $\mathrm{~N}$ & $\mathrm{~N}$ & $\mathrm{~N}$ & $\mathrm{~N}$ & $\mathrm{~N}$ & Normal \\
\hline 2 & $\bar{N}$ & $\mathrm{~N}$ & $\bar{N}$ & $\mathrm{~N}$ & $\mathrm{~N}$ & $\mathrm{~N}$ & $\mathrm{H}$ & $\mathrm{N}$ & $\bar{L}$ & JD \\
\hline 3 & $\mathrm{~N}$ & $\mathrm{~N}$ & $\mathrm{~N}$ & $\mathrm{H}$ & $\mathrm{H}$ & $\mathrm{H}$ & $\mathrm{N}$ & $\mathrm{N}$ & $\mathrm{N}$ & UTI \\
\hline 4 & $\mathrm{~N}$ & $\mathrm{~N}$ & $\mathrm{~N}$ & $\mathrm{~N}$ & $\mathrm{H}$ & $\mathrm{H}$ & $\mathrm{N}$ & $\mathrm{N}$ & $\mathrm{N}$ & UTI \\
\hline 5 & $\mathrm{~N}$ & $\mathrm{~N}$ & $\mathrm{~N}$ & $\mathrm{H}$ & $\mathrm{H}$ & $\mathrm{N}$ & $\mathrm{N}$ & $\mathrm{N}$ & $\mathrm{N}$ & UTI \\
\hline 6 & $\mathrm{~N}$ & $\mathrm{~N}$ & $\mathrm{~N}$ & $\mathrm{~N}$ & $\mathrm{~N}$ & $\mathrm{~N}$ & $\mathrm{~N}$ & $\mathrm{H}$ & $\mathrm{N}$ & JD \\
\hline 7 & $\overline{\mathrm{H}}$ & $\mathrm{N}$ & $\bar{N}$ & $\mathrm{~N}$ & $\mathrm{~N}$ & $\mathrm{~N}$ & $\mathrm{~N}$ & $\bar{N}$ & $\bar{N}$ & MELT \\
\hline 8 & $\mathrm{H}$ & $\mathrm{N}$ & $\mathrm{H}$ & $\mathrm{N}$ & $\mathrm{N}$ & $\mathrm{N}$ & $\mathrm{N}$ & $\mathrm{N}$ & $\mathrm{N}$ & MELT \\
\hline 9 & $\overline{\mathrm{H}}$ & $\mathrm{L}$ & $\overline{\mathrm{H}}$ & $\overline{\mathrm{N}}$ & $\mathrm{N}$ & $\bar{N}$ & $\mathrm{~N}$ & $\bar{N}$ & $\mathrm{~N}$ & MELT \\
\hline 10 & $\mathrm{H}$ & $\mathrm{L}$ & $\mathrm{N}$ & $\mathrm{N}$ & $\mathrm{N}$ & $\mathrm{N}$ & $\mathrm{N}$ & $\mathrm{N}$ & $\mathrm{N}$ & MELT \\
\hline 11 & $\mathrm{~L}$ & $\mathrm{~N}$ & $\bar{N}$ & $\mathrm{~N}$ & $\mathrm{~N}$ & $\mathrm{~N}$ & $\mathrm{~N}$ & $\overline{\mathrm{N}}$ & $\overline{\mathrm{N}}$ & MELT \\
\hline 12 & $\mathrm{~L}$ & $\mathrm{~N}$ & $\mathrm{H}$ & $\mathrm{N}$ & $\mathrm{N}$ & $\mathrm{N}$ & $\mathrm{N}$ & $\mathrm{N}$ & $\mathrm{N}$ & MELT \\
\hline 13 & $\mathrm{~N}$ & $\mathrm{~N}$ & $\mathrm{~N}$ & $\mathrm{H}$ & $\mathrm{H}$ & $\mathrm{H}$ & $\mathrm{H}$ & $\mathrm{N}$ & $\mathrm{L}$ & UTI\& JD \\
\hline 14 & $\mathrm{~N}$ & $\mathrm{~N}$ & $\mathrm{~N}$ & $\mathrm{~N}$ & $\mathrm{H}$ & $\mathrm{H}$ & $\mathrm{H}$ & $\mathrm{N}$ & $\mathrm{L}$ & UTI\& JD \\
\hline 15 & $\mathrm{~N}$ & $\mathrm{~N}$ & $\mathrm{~N}$ & $\mathrm{H}$ & $\mathrm{H}$ & $\mathrm{N}$ & $\mathrm{H}$ & $\mathrm{N}$ & $\mathrm{L}$ & UTI\& JD \\
\hline 16 & $\bar{N}$ & $\mathrm{~N}$ & $\bar{N}$ & $\mathrm{~N}$ & $\mathrm{H}$ & $\mathrm{H}$ & $\mathrm{N}$ & $\overline{\mathrm{H}}$ & $\mathrm{N}$ & UTI\& JD \\
\hline 17 & $\mathrm{~N}$ & $\mathrm{~N}$ & $\mathrm{~N}$ & $\mathrm{H}$ & $\mathrm{H}$ & $\mathrm{N}$ & $\mathrm{N}$ & $\mathrm{H}$ & $\mathrm{N}$ & UTI\& JD \\
\hline 18 & $\mathrm{~N}$ & $\mathrm{~N}$ & $\mathrm{~N}$ & $\mathrm{H}$ & $\mathrm{H}$ & $\mathrm{H}$ & $\mathrm{N}$ & $\mathrm{H}$ & $\mathrm{N}$ & UTI\& JD \\
\hline 19 & $\mathrm{H}$ & $\mathrm{N}$ & $\mathrm{N}$ & $\mathrm{N}$ & $\mathrm{N}$ & $\mathrm{N}$ & $\mathrm{H}$ & $\mathrm{N}$ & $\mathrm{L}$ & MELT\& JD \\
\hline 20 & $\mathrm{H}$ & $\mathrm{N}$ & $\mathrm{N}$ & $\mathrm{N}$ & $\mathrm{N}$ & $\mathrm{N}$ & $\mathrm{N}$ & $\mathrm{H}$ & $\mathrm{N}$ & MELT\& JD \\
\hline 21 & $\mathrm{H}$ & $\mathrm{L}$ & $\mathrm{N}$ & $\mathrm{N}$ & $\mathrm{N}$ & $\mathrm{N}$ & $\mathrm{H}$ & $\mathrm{N}$ & $\mathrm{L}$ & MELT\& JD \\
\hline 22 & $\mathrm{H}$ & $\mathrm{L}$ & $\mathrm{N}$ & $\mathrm{N}$ & $\mathrm{N}$ & $\mathrm{N}$ & $\mathrm{N}$ & $\overline{\mathrm{H}}$ & $\mathrm{N}$ & MELT\& JD \\
\hline 23 & $\overline{\mathrm{H}}$ & $\mathrm{N}$ & $\overline{\mathrm{H}}$ & $\mathrm{N}$ & $\mathrm{N}$ & $\mathrm{N}$ & $\mathrm{H}$ & $\mathrm{N}$ & $\mathrm{L}$ & MELT\& JD \\
\hline 24 & $\mathrm{H}$ & $\mathrm{N}$ & $\mathrm{H}$ & $\mathrm{N}$ & $\mathrm{N}$ & $\mathrm{N}$ & $\mathrm{N}$ & $\mathrm{H}$ & $\mathrm{N}$ & MELT\& JD \\
\hline 25 & $\mathrm{H}$ & $\mathrm{L}$ & $\mathrm{H}$ & $\mathrm{N}$ & $\mathrm{N}$ & $\mathrm{N}$ & $\mathrm{H}$ & $\mathrm{N}$ & $\mathrm{L}$ & MELT\& JD \\
\hline 26 & $\mathrm{H}$ & $\mathrm{L}$ & $\mathrm{H}$ & $\mathrm{N}$ & $\mathrm{N}$ & $\mathrm{N}$ & $\mathrm{N}$ & $\mathrm{H}$ & $\mathrm{N}$ & MELT\& JD \\
\hline 27 & $\mathrm{~L}$ & $\mathrm{~N}$ & $\mathrm{~N}$ & $\mathrm{~N}$ & $\mathrm{~N}$ & $\mathrm{~N}$ & $\mathrm{H}$ & $\mathrm{N}$ & $\mathrm{L}$ & MELT\& JD \\
\hline 28 & $\mathrm{~L}$ & $\mathrm{~N}$ & $\bar{N}$ & $\overline{\mathrm{N}}$ & $\mathrm{N}$ & $\mathrm{N}$ & $\mathrm{N}$ & $\overline{\mathrm{H}}$ & $\mathrm{N}$ & MELT\& JD \\
\hline 29 & $\mathrm{~L}$ & $\mathrm{~N}$ & $\mathrm{H}$ & $\mathrm{N}$ & $\mathrm{N}$ & $\mathrm{N}$ & $\mathrm{N}$ & $\mathrm{H}$ & $\mathrm{N}$ & MELT\& JD \\
\hline 30 & $\mathrm{~L}$ & $\mathrm{~N}$ & $\mathrm{H}$ & $\mathrm{N}$ & $\mathrm{N}$ & $\mathrm{N}$ & $\mathrm{H}$ & $\mathrm{N}$ & $\mathrm{L}$ & MELT\& JD \\
\hline 31 & $\mathrm{H}$ & $\mathrm{N}$ & $\mathrm{N}$ & $\mathrm{N}$ & $\mathrm{H}$ & $\mathrm{H}$ & $\mathrm{N}$ & $\mathrm{N}$ & $\mathrm{N}$ & UTI\& MELT \\
\hline 32 & $\mathrm{H}$ & $\mathrm{N}$ & $\mathrm{N}$ & $\mathrm{H}$ & $\mathrm{H}$ & $\mathrm{N}$ & $\mathrm{N}$ & $\mathrm{N}$ & $\mathrm{N}$ & UTI\& MELT \\
\hline 33 & $\mathrm{H}$ & $\mathrm{N}$ & $\bar{N}$ & $\overline{\mathrm{H}}$ & $\mathrm{H}$ & $\mathrm{H}$ & $\mathrm{N}$ & $\bar{N}$ & $\mathrm{~N}$ & UTI\& MELT \\
\hline 34 & $\mathrm{H}$ & $\mathrm{L}$ & $\mathrm{N}$ & $\mathrm{N}$ & $\mathrm{H}$ & $\mathrm{H}$ & $\mathrm{N}$ & $\mathrm{N}$ & $\mathrm{N}$ & UTI\& MELT \\
\hline 35 & $\mathrm{H}$ & $\mathrm{L}$ & $\mathrm{N}$ & $\mathrm{H}$ & $\mathrm{H}$ & $\mathrm{N}$ & $\mathrm{N}$ & $\mathrm{N}$ & $\mathrm{N}$ & UTI\& MELT \\
\hline 36 & $\mathrm{H}$ & $\mathrm{N}$ & $\mathrm{H}$ & $\mathrm{H}$ & $\mathrm{H}$ & $\mathrm{H}$ & $\mathrm{N}$ & $\mathrm{N}$ & $\mathrm{N}$ & UTI\& MELT \\
\hline 37 & $\mathrm{H}$ & $\mathrm{N}$ & $\mathrm{H}$ & $\mathrm{N}$ & $\mathrm{H}$ & $\mathrm{H}$ & $\mathrm{N}$ & $\mathrm{N}$ & $\mathrm{N}$ & UTI\& MELT \\
\hline 38 & $\mathrm{H}$ & $\mathrm{N}$ & $\mathrm{H}$ & $\mathrm{H}$ & $\mathrm{H}$ & $\mathrm{N}$ & $\mathrm{N}$ & $\mathrm{N}$ & $\mathrm{N}$ & UTI\& MELT \\
\hline 39 & $\mathrm{H}$ & $\mathrm{L}$ & $\mathrm{H}$ & $\mathrm{H}$ & $\mathrm{H}$ & $\mathrm{H}$ & $\mathrm{N}$ & $\mathrm{N}$ & $\mathrm{N}$ & UTI\& MELT \\
\hline 40 & $\mathrm{H}$ & $\mathrm{L}$ & $\mathrm{H}$ & $\mathrm{N}$ & $\mathrm{H}$ & $\mathrm{H}$ & $\mathrm{N}$ & $\mathrm{N}$ & $\mathrm{N}$ & UTI\& MELT \\
\hline 41 & $\mathrm{H}$ & $\mathrm{L}$ & $\mathrm{H}$ & $\mathrm{H}$ & $\mathrm{H}$ & $\mathrm{N}$ & $\mathrm{N}$ & $\mathrm{N}$ & $\mathrm{N}$ & UTI\& MELT \\
\hline
\end{tabular}




\begin{tabular}{|c|c|c|c|c|c|c|c|c|c|c|}
\hline 42 & $\mathrm{~L}$ & $\mathrm{~N}$ & $\mathrm{~N}$ & $\mathrm{H}$ & $\mathrm{H}$ & $\mathrm{H}$ & $\mathrm{N}$ & $\mathrm{N}$ & $\mathrm{N}$ & \begin{tabular}{|l|} 
UTI\& MELT \\
\end{tabular} \\
\hline 43 & $\mathrm{~L}$ & $\mathrm{~N}$ & $\mathrm{~N}$ & $\mathrm{~N}$ & $\mathrm{H}$ & $\mathrm{H}$ & $\mathrm{N}$ & $\mathrm{N}$ & $\mathrm{N}$ & UTI\& MELT \\
\hline 44 & $\mathrm{~L}$ & $\mathrm{~N}$ & $\mathrm{~N}$ & $\mathrm{H}$ & $\mathrm{H}$ & $\mathrm{N}$ & $\mathrm{N}$ & $\mathrm{N}$ & $\mathrm{N}$ & UTI\& MELT \\
\hline 45 & $\mathrm{~L}$ & $\mathrm{~N}$ & $\mathrm{H}$ & $\mathrm{H}$ & $\mathrm{H}$ & $\mathrm{H}$ & $\mathrm{N}$ & $\mathrm{N}$ & $\mathrm{N}$ & \begin{tabular}{|l|} 
UTI\& MELT \\
\end{tabular} \\
\hline 46 & $\mathrm{~L}$ & $\mathrm{~N}$ & $\mathrm{H}$ & $\mathrm{N}$ & $\mathrm{H}$ & $\mathrm{H}$ & $\mathrm{N}$ & $\mathrm{N}$ & $\mathrm{N}$ & UTI\& MELT \\
\hline 47 & $\mathrm{~L}$ & $\mathrm{~N}$ & $\mathrm{H}$ & $\mathrm{H}$ & $\mathrm{H}$ & $\mathrm{N}$ & $\mathrm{N}$ & $\mathrm{N}$ & $\mathrm{N}$ & UTI\& MELT \\
\hline 48 & $\mathrm{H}$ & $\mathrm{L}$ & $\mathrm{N}$ & $\mathrm{H}$ & $\mathrm{H}$ & $\mathrm{H}$ & $\mathrm{N}$ & $\mathrm{N}$ & $\mathrm{N}$ & UTI\& MELT \\
\hline 49 & $\mathrm{H}$ & $\mathrm{N}$ & $\mathrm{N}$ & $\mathrm{H}$ & $\mathrm{H}$ & $\mathrm{H}$ & $\mathrm{H}$ & $\mathrm{N}$ & $\mathrm{L}$ & $\begin{array}{c}\text { UTI, JD\& } \\
\text { MELT }\end{array}$ \\
\hline 50 & $\mathrm{H}$ & $\mathrm{N}$ & $\mathrm{N}$ & $\mathrm{N}$ & $\mathrm{H}$ & $\mathrm{H}$ & $\mathrm{H}$ & $\mathrm{N}$ & $\mathrm{L}$ & $\begin{array}{c}\text { UTI, JD\& } \\
\text { MELT }\end{array}$ \\
\hline 51 & $\mathrm{H}$ & $\mathrm{N}$ & $\mathrm{N}$ & $\mathrm{H}$ & $\mathrm{H}$ & $\mathrm{N}$ & $\mathrm{H}$ & $\mathrm{N}$ & $\mathrm{L}$ & $\begin{array}{c}\text { UTI, JD\& } \\
\text { MELT }\end{array}$ \\
\hline 52 & $\mathrm{H}$ & $\mathrm{N}$ & $\mathrm{N}$ & $\mathrm{H}$ & $\mathrm{H}$ & $\mathrm{H}$ & $\mathrm{N}$ & $\mathrm{H}$ & $\mathrm{N}$ & $\begin{array}{c}\text { UTI, JD\& } \\
\text { MELT }\end{array}$ \\
\hline 53 & $\mathrm{H}$ & $\mathrm{N}$ & $\mathrm{N}$ & $\mathrm{N}$ & $\mathrm{H}$ & $\mathrm{H}$ & $\mathrm{N}$ & $\mathrm{H}$ & $\mathrm{N}$ & $\begin{array}{c}\text { UTI, JD\& } \\
\text { MELT }\end{array}$ \\
\hline 54 & $\mathrm{H}$ & $\mathrm{N}$ & $\mathrm{N}$ & $\mathrm{H}$ & $\mathrm{H}$ & $\mathrm{N}$ & $\mathrm{N}$ & $\mathrm{H}$ & $\mathrm{N}$ & $\begin{array}{c}\text { UTI, JD\& } \\
\text { MELT }\end{array}$ \\
\hline 55 & $\mathrm{H}$ & $\mathrm{N}$ & $\mathrm{H}$ & $\mathrm{H}$ & $\mathrm{H}$ & $\mathrm{H}$ & $\mathrm{H}$ & $\mathrm{N}$ & $\mathrm{L}$ & $\begin{array}{l}\text { UTI, JD\& } \\
\text { MELT }\end{array}$ \\
\hline 56 & $\mathrm{H}$ & $\mathrm{N}$ & $\mathrm{H}$ & $\mathrm{N}$ & $\mathrm{H}$ & $\mathrm{H}$ & $\mathrm{H}$ & $\mathrm{N}$ & $\mathrm{L}$ & $\begin{array}{c}\text { UTI, JD\& } \\
\text { MELT }\end{array}$ \\
\hline 57 & $\mathrm{H}$ & $\mathrm{N}$ & $\mathrm{H}$ & $\mathrm{H}$ & $\mathrm{H}$ & $\mathrm{N}$ & $\mathrm{H}$ & $\mathrm{N}$ & $\mathrm{L}$ & $\begin{array}{l}\text { UTI, JD\& } \\
\text { MELT }\end{array}$ \\
\hline 58 & $\mathrm{H}$ & $\mathrm{N}$ & $\mathrm{H}$ & $\mathrm{H}$ & $\mathrm{H}$ & $\mathrm{H}$ & $\mathrm{N}$ & $\mathrm{H}$ & $\mathrm{N}$ & $\begin{array}{l}\text { UTI, JD\& } \\
\text { MELT }\end{array}$ \\
\hline 59 & $\mathrm{H}$ & $\mathrm{N}$ & $\mathrm{H}$ & $\mathrm{N}$ & $\mathrm{H}$ & $\mathrm{H}$ & $\mathrm{N}$ & $\mathrm{H}$ & $\mathrm{N}$ & $\begin{array}{l}\text { UTI, JD\& } \\
\text { MELT }\end{array}$ \\
\hline 60 & $\mathrm{H}$ & $\mathrm{N}$ & $\mathrm{H}$ & $\mathrm{H}$ & $\mathrm{H}$ & $\mathrm{N}$ & $\mathrm{N}$ & $\mathrm{H}$ & $\mathrm{N}$ & $\begin{array}{c}\text { UTI, JD\& } \\
\text { MELT }\end{array}$ \\
\hline 61 & $\mathrm{H}$ & $\mathrm{L}$ & $\mathrm{H}$ & $\mathrm{H}$ & $\mathrm{H}$ & $\mathrm{H}$ & $\mathrm{H}$ & $\mathrm{N}$ & $\mathrm{L}$ & $\begin{array}{c}\text { UTI, JD\& } \\
\text { MELT }\end{array}$ \\
\hline 62 & $\mathrm{H}$ & $\mathrm{L}$ & $\mathrm{H}$ & $\mathrm{N}$ & $\mathrm{H}$ & $\mathrm{H}$ & $\mathrm{H}$ & $\mathrm{N}$ & $\mathrm{L}$ & $\begin{array}{l}\text { UTI, JD\& } \\
\text { MELT }\end{array}$ \\
\hline 63 & $\mathrm{H}$ & $\mathrm{L}$ & $\mathrm{H}$ & $\mathrm{H}$ & $\mathrm{H}$ & $\mathrm{N}$ & $\mathrm{H}$ & $\mathrm{N}$ & $\mathrm{L}$ & $\begin{array}{c}\text { UTI, JD\& } \\
\text { MELT }\end{array}$ \\
\hline 64 & $\mathrm{H}$ & $\mathrm{L}$ & $\mathrm{H}$ & $\mathrm{H}$ & $\mathrm{H}$ & $\mathrm{H}$ & $\mathrm{N}$ & $\mathrm{H}$ & $\mathrm{N}$ & $\begin{array}{c}\text { UTI, JD\& } \\
\text { MELT }\end{array}$ \\
\hline 65 & $\mathrm{H}$ & $\mathrm{L}$ & $\mathrm{H}$ & $\mathrm{N}$ & $\mathrm{H}$ & $\mathrm{H}$ & $\mathrm{N}$ & $\mathrm{H}$ & $\mathrm{N}$ & $\begin{array}{c}\text { UTI, JD\& } \\
\text { MELT }\end{array}$ \\
\hline 66 & $\mathrm{H}$ & $\mathrm{L}$ & $\mathrm{H}$ & $\mathrm{H}$ & $\mathrm{H}$ & $\mathrm{N}$ & $\mathrm{N}$ & $\mathrm{H}$ & $\mathrm{N}$ & $\begin{array}{c}\text { UTI, JD\& } \\
\text { MELT }\end{array}$ \\
\hline 67 & $\mathrm{H}$ & $\mathrm{L}$ & $\mathrm{N}$ & $\mathrm{H}$ & $\mathrm{H}$ & $\mathrm{H}$ & $\mathrm{H}$ & $\mathrm{N}$ & $\mathrm{L}$ & $\begin{array}{l}\text { UTI, JD\& } \\
\text { MELT }\end{array}$ \\
\hline 68 & $\mathrm{H}$ & $\mathrm{L}$ & $\mathrm{N}$ & $\mathrm{N}$ & $\mathrm{H}$ & $\mathrm{H}$ & $\mathrm{H}$ & $\mathrm{N}$ & $\mathrm{L}$ & $\begin{array}{l}\text { UTI, JD\& } \\
\text { MELT }\end{array}$ \\
\hline
\end{tabular}


Nada Nimat Saleem \& Adepa Ismaeel and Fatin George

\begin{tabular}{||c||c|c|c|c|c|c|c|c|c|c||}
\hline 69 & $\mathrm{H}$ & $\mathrm{L}$ & $\mathrm{N}$ & $\mathrm{H}$ & $\mathrm{H}$ & $\mathrm{N}$ & $\mathrm{H}$ & $\mathrm{N}$ & $\mathrm{L}$ & $\begin{array}{c}\text { UTI, JD\& } \\
\text { MELT }\end{array}$ \\
\hline 70 & $\mathrm{H}$ & $\mathrm{L}$ & $\mathrm{N}$ & $\mathrm{H}$ & $\mathrm{H}$ & $\mathrm{H}$ & $\mathrm{N}$ & $\mathrm{H}$ & $\mathrm{N}$ & $\begin{array}{c}\text { UTI, JD\& } \\
\text { MELT }\end{array}$ \\
\hline 71 & $\mathrm{H}$ & $\mathrm{L}$ & $\mathrm{N}$ & $\mathrm{N}$ & $\mathrm{H}$ & $\mathrm{H}$ & $\mathrm{N}$ & $\mathrm{H}$ & $\mathrm{N}$ & $\begin{array}{c}\text { UTI, JD\& } \\
\text { MELT }\end{array}$ \\
\hline 72 & $\mathrm{H}$ & $\mathrm{L}$ & $\mathrm{N}$ & $\mathrm{H}$ & $\mathrm{H}$ & $\mathrm{N}$ & $\mathrm{N}$ & $\mathrm{H}$ & $\mathrm{N}$ & $\begin{array}{c}\text { UTI, JD\& } \\
\text { MELT }\end{array}$ \\
\hline 73 & $\mathrm{~L}$ & $\mathrm{~N}$ & $\mathrm{~N}$ & $\mathrm{H}$ & $\mathrm{H}$ & $\mathrm{H}$ & $\mathrm{H}$ & $\mathrm{N}$ & $\mathrm{L}$ & $\begin{array}{c}\text { UTI, JD\& } \\
\text { MELT }\end{array}$ \\
\hline 74 & $\mathrm{~L}$ & $\mathrm{~N}$ & $\mathrm{~N}$ & $\mathrm{~N}$ & $\mathrm{H}$ & $\mathrm{H}$ & $\mathrm{H}$ & $\mathrm{N}$ & $\mathrm{L}$ & $\begin{array}{c}\text { UTI, JD\& } \\
\text { MELT }\end{array}$ \\
\hline 75 & $\mathrm{~L}$ & $\mathrm{~N}$ & $\mathrm{~N}$ & $\mathrm{H}$ & $\mathrm{H}$ & $\mathrm{N}$ & $\mathrm{H}$ & $\mathrm{N}$ & $\mathrm{L}$ & $\begin{array}{c}\text { UTI, JD\& } \\
\text { MELT }\end{array}$ \\
\hline 76 & $\mathrm{~L}$ & $\mathrm{~N}$ & $\mathrm{~N}$ & $\mathrm{H}$ & $\mathrm{H}$ & $\mathrm{H}$ & $\mathrm{N}$ & $\mathrm{H}$ & $\mathrm{N}$ & $\begin{array}{c}\text { UTI, JD\& } \\
\text { MELT }\end{array}$ \\
\hline 77 & $\mathrm{~L}$ & $\mathrm{~N}$ & $\mathrm{~N}$ & $\mathrm{~N}$ & $\mathrm{H}$ & $\mathrm{H}$ & $\mathrm{N}$ & $\mathrm{H}$ & $\mathrm{N}$ & $\begin{array}{c}\text { UTI, JD\& } \\
\text { MELT }\end{array}$ \\
\hline 78 & $\mathrm{~L}$ & $\mathrm{~N}$ & $\mathrm{~N}$ & $\mathrm{H}$ & $\mathrm{H}$ & $\mathrm{N}$ & $\mathrm{N}$ & $\mathrm{H}$ & $\mathrm{N}$ & $\begin{array}{c}\text { UTI, JD\& } \\
\text { MELT }\end{array}$ \\
\hline 79 \\
\cline { 1 - 11 } & $\mathrm{L}$ & $\mathrm{N}$ & $\mathrm{H}$ & $\mathrm{H}$ & $\mathrm{H}$ & $\mathrm{H}$ & $\mathrm{H}$ & $\mathrm{N}$ & $\mathrm{L}$ & $\begin{array}{c}\text { UTI, JD\& } \\
\text { MELT }\end{array}$ \\
\hline 80 & $\mathrm{~L}$ & $\mathrm{~N}$ & $\mathrm{H}$ & $\mathrm{N}$ & $\mathrm{H}$ & $\mathrm{H}$ & $\mathrm{H}$ & $\mathrm{N}$ & $\mathrm{L}$ & $\begin{array}{c}\text { UTI, JD\& } \\
\text { MELT }\end{array}$ \\
\hline 81 \\
\hline $\mathrm{L}$ & $\mathrm{N}$ & $\mathrm{H}$ & $\mathrm{H}$ & $\mathrm{H}$ & $\mathrm{N}$ & $\mathrm{H}$ & $\mathrm{N}$ & $\mathrm{L}$ & $\begin{array}{c}\text { UTI, JD\& } \\
\text { MELT }\end{array}$ \\
\hline 82 \\
\hline $\mathrm{H}$ & $\mathrm{N}$ & $\mathrm{H}$ & $\mathrm{H}$ & $\mathrm{H}$ & $\mathrm{H}$ & $\mathrm{N}$ & $\mathrm{H}$ & $\mathrm{N}$ & $\begin{array}{c}\text { UTI, JD\& } \\
\text { MELT }\end{array}$ \\
\hline 83 \\
\hline $\mathrm{L}$ & $\mathrm{N}$ & $\mathrm{H}$ & $\mathrm{N}$ & $\mathrm{H}$ & $\mathrm{H}$ & $\mathrm{N}$ & $\mathrm{H}$ & $\mathrm{N}$ & $\begin{array}{c}\text { UTI, JD\& } \\
\text { MELT }\end{array}$ \\
\hline 84 \\
\hline $\mathrm{L}$ & $\mathrm{N}$ & $\mathrm{H}$ & $\mathrm{H}$ & $\mathrm{H}$ & $\mathrm{N}$ & $\mathrm{N}$ & $\mathrm{H}$ & $\mathrm{N}$ & $\begin{array}{c}\text { UTI, JD\& } \\
\text { MELT }\end{array}$ \\
\hline \hline
\end{tabular}

